\title{
FATTENING AND SLAUGHTER RESULTS ANALYSIS OF HEREFORD BREED BULLS BORN IN DIFFERENT SEASONS
}

\begin{abstract}
Inga MUIZNIECE, Institute of Agrobiotechnology, Faculty of Agriculture, Latvia University of Agriculture, Lielā iela 2, Jelgava, Latvia, LV - 3001, e-mail: muiznieceinga@ inbox.lv (corresponding author)

Daina KAIRISA, Institute of Agrobiotechnology, Faculty of Agriculture, Latvia University of Agriculture, Lielā iela 2, Jelgava, Latvia, LV - 3001, e-mail: daina.kairisa@1lu.lv

The aim of this study was to explain the birth season effect on Hereford bulls fattening results. The research was made within the project 'Baltic Grassland Beef' framework in years 2015 and 2016. Data about 41 Herford purebred bull was used in the research, grown in different farms of Latvia. Bulls were slaughtered in certified slaughterhouse 'Agaras' (Lithuania). The average birth weight of the Hereford breed bulls was in border from $42.9-45.0 \mathrm{~kg}$. The lowest birth weight was on spring season born bulls $-42.9 \mathrm{~kg}$, but the highest on winter season born bulls - 45.0. Average realization age of bull's, in the research groups, was on range from 567 days to 661 days. Bulls born on autumn and winter before slaughtering were significantly older, respectively 661 and 655 days with live weight of $519.9 \mathrm{~kg}$ un $542.1 \mathrm{~kg}$. On spring born bulls with age 600 days reached the biggest live weight $-542.0 \mathrm{~kg}$, respectively these group bulls average daily weight gain from birth to slaughter per day was the biggest among all the groups $-831.9 \mathrm{~g}$. The highest slaughter weight showed on autumn and winter seasons born bulls, respectively $275.5 \mathrm{~kg}$ and $274.8 \mathrm{~kg}$. In the research groups on different seasons born bulls conformation score was from points 2.4 to 2.6. All the bull's carcass in the research groups were evaluated as 2 nd and 3rd fat class. between the age before slaughter and average daily weight gain from birth to slaughter there is an important negative correlation (from $r=-0.858$ to $=-0.977, p<0.05$ ), except on spring season born bulls.
\end{abstract}

Keywords: Hereford bulls, beef cattle fattening, growth, carcass characteristics

\section{INTRODUCTION}

Considering the current economic situation in Latvia, cattle fattening should be inexpensive and profitable to the farmer. Profitability of beef cattle production is highly dependent upon cost of production. The largest variable cost associated with cow/calf production is feed cost (May et.al., 1992). One strategy to reduce cost is to extend the grazing season because allowing cows to graze costs less than mechanically harvesting and feeding forage. Selecting a calving date that matches the cow's nutrient requirements with grazed forage nutrient content has the potential to reduce costs (Adams et al., 1996; Stockton et al., 2007). Two critical decisions that cow-calf producers can make are season of calving and time of weaning. These decisions may also affect post weaning calf performance and carcass traits (Thrift, Thrift, 2004).

Many factors affect ruminant carcass and meat quality, and among the genetic and environmental factors, feeding plays an important role in the determination of quality (Dannenberger et.al., 2006). Grass forage in Latvian weather conditions is the cheapest feeding material for summer period that is why it is important to use benefits of this season, to produce production with lower cost price. Farms where calves are born in spring season, cattle fattening period can be used 2 summer seasons (during lactation and in direct fattening period). Providing high level of pasture in lactation period, it is possible to achieve good weaning results. Also, using pasture fattening at the final stage, it is possible increase livestock growth, reducing the cost of produced meat.

Beef production economic efficiency depends on the grass yield and quality - the more economical is the feed obtained, the higher they are. Grassland productivity level and quality of the harvest can be meaningfully regulated, as they depend on the sward botanical composition and density. Grass dry matter contains all the necessary nutrients for animals, which allows us to get delicious and biologically wholesome meat, but at the same time ensures quality and quantity rising of meat (Lujane et. al., 2013). The quality and quantity of forage has impressive meaning to fattening forage providing intensity of growth and obtaining qualitative carcass. The fundamental purpose of beef cattle growing is to produce highquality beef. Carcass yield and good muscularity and fat class are important factors for beef production profitability. Muscularity classification indicates of carcasses development, structure and quality (Pečiulaitiene et. al., 2015).

Copyright (C) 2017 The Authors. Published by Aleksandras Stulginskis University. This is an open-access article distributed under the terms of the Creative Commons Attribution License (CC-BY 4.0), which permits unrestricted use, distribution, and reproduction in any medium, provided the original author and source are credited. 
The season also influence fattening cattle dry matter absorption. It is found that in winter period dry matter absorption is lower than in others. Authors explain that as less consumption of water and decreased forage digestibility (Koknaroglu et. al., 2005).

The aim of this study was to explain the birth season effect on Hereford bulls fattening results.

\section{MATERIAL AND METHODS}

The research was made within the project 'Baltic Grassland Beef' framework in years 2015 and 2016. For bull fattening the forage was used, in winter - silage and hay, in summer- pasture grass, silage and hay.

Data about 41 Herford purebred bull was used in the research, grown in different farms of Latvia. Bulls were slaughtered in certified slaughterhouse 'Agaras' (Lithuania).

For data analysis following scheme was create:

Group 1 (Sp.S) - on spring season (March, April, May) born bulls;

Group 2 (So.S.) - on summer season (June, July, August) born bulls;

Group 3 (Au.S) - on autumn season (September, October, November) born bulls;

Group 4 (Wi.S) - on winter season (December, January, February) born bulls.

In the research bulls, whose age before slaughtering did not exceed two years, was used.

Data about bull's origin, belonging breed, time of birth and mass was obtained from register of Latvian Agricultural data center. Slaughtering results - slaughtering date, live weight before slaughtering, cold carcass weight, conformation and fat score was taken from registered data in slaughterhouse.

Used formula for calculating average live weight growth:

$$
a=\frac{(W t-W 0)}{t} \times 1000
$$

where $\quad \mathrm{a}$-daily weight gain from birth to slaughter per day, $\mathrm{g}$

$\mathrm{Wt}$ - live weight before slaughtering, $\mathrm{kg}$

W0 - born weight, $\mathrm{kg}$

$\mathrm{t}$ - age before slaughter, in days

From obtained slaughtering data, dressing percentage was calculated:

$$
k=\frac{W k}{W t} \times 100
$$

where $\mathrm{k}$-dressing percentage, $\%$

$\mathrm{Wk}$ - slaughter weight, $\mathrm{kg}$

$\mathrm{Wt}$ - live weight before slaughter, $\mathrm{kg}$

To compare in the research used bull's live weight before slaughtering, it has been corrected to 600 days old, using daily weight gain from birth to slaughter per day:

$$
W 600=\frac{a \times 600}{1000}+W 0
$$

where W600 - corrected live weight at age of 600 days, $\mathrm{kg}$

$\mathrm{a}=$ daily weight gain from birth to slaughter per day, $\mathrm{g}$

W0 - birth weight, $\mathrm{kg}$

After bull's slaughtering, their carcasses weighing and musculature development, according to classification of SEUROP, was made. To marking evaluation of conformation development following letter marks of EUROP with following meaning were used: $\mathrm{E}$ - excellent (numerical symbol - 5), $\mathrm{U}$ - very good (4), R - good (3), O - medium (2), $\mathrm{P}$ - poor (1) muscle development. Evaluation of development of fat marked with the help of numbers from 1 to 5, where 1 - very low, 2 - low, 3 - moderate, 4 - high, 5 - very high.

Analysis of the data acquired was based on the indicators of descriptive statistics: arithmetical mean, standard error and coefficient of variation. T-test for average values was used for significance determination. Different letters (a, $\mathrm{b}, \mathrm{c}$ ) on tables mark significant differences at $\mathrm{p} \leq 0.05$. For trait relationship, correlation analysis was performed.

\section{RESULTS AND DISCUSSIONS}

On spring season born bulls group were 15, on summer season group - 5, on autumn season group - 7 and on winter season group - 14 animals. The average birth weight of the Hereford breed bulls was in border from 42.9 bulls $45.0 \mathrm{~kg}$. The lowest birth weight was on spring season born bulls $-42.9 \mathrm{~kg}$, but the highest on winter season born bulls bulls $45.0 \mathrm{~kg}$. However, a significant difference of birth weight was not detected. Other researchers (Dadi, Jordaan et. al., 
2002; Krupa et al., 2005) found that average Hereford calves birth weight ranged from 29.3 - $34.6 \mathrm{~kg}$ which was lower than that found in our study.

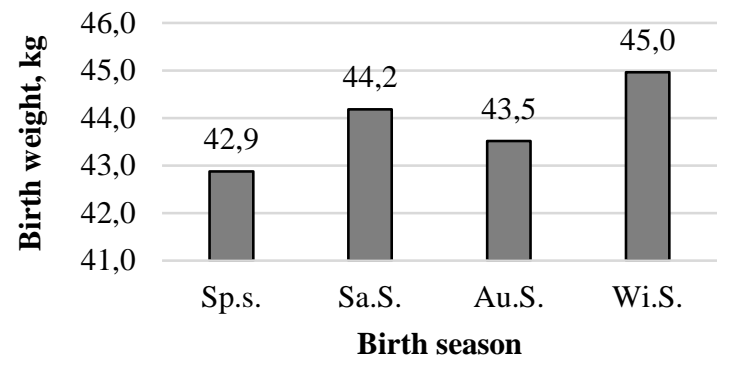

Figure 1. Bull's birth weight in groups of the research, $\mathrm{kg}$

Average realization age of bull's, in the research groups, was on range from 567 days to 661 days (Table 1). Bulls born on autumn and winter before slaughtering were significantly older, respectively 661 and 655 days with live weight of $519.9 \mathrm{~kg}$ un $542.1 \mathrm{~kg}$. On autumn season born bull's average realization age was of 70 days bigger than on spring season, and about 94 days bigger than bulls average realization age born on summer season ( $\mathrm{p} \leq 0.05$ ). But bulls born on winter season were realized about 64 days older than spring and about 88 days older than born bulls on summer season $(\mathrm{p} \leq 0.05)$. On winter season born bulls live weight before slaughtering was about $8.0 \mathrm{~kg}$ more than on spring season born bulls live weight of slaughtering, for $44.3 \mathrm{~kg}(\mathrm{p} \leq 0.05)$ more than on summer season born bulls live weight and for 22.2 $\mathrm{kg}(\mathrm{p} \leq 0.05)$ more than on autumn season born bulls live weight before slaughtering.

Table 1. On different seasons born Hereford purebred bull fattening results

\begin{tabular}{|l|c|c|c|c|c|c|c|c|}
\hline \multirow{2}{*}{\multicolumn{1}{|c}{ Indicators }} & \multicolumn{2}{|c|}{ Sp.S. bulls } & \multicolumn{2}{c|}{ So.S. bulls } & \multicolumn{2}{c|}{ Au.S. bulls } & \multicolumn{2}{c|}{ Wi.S. bulls } \\
\cline { 2 - 9 } & $\begin{array}{c}\mathrm{x} \pm \mathrm{Sx} \\
(\mathrm{n}-15)\end{array}$ & $\mathrm{V} \%$ & $\begin{array}{c}\mathrm{x} \pm \mathrm{Sx} \\
(\mathrm{n}-5)\end{array}$ & $\mathrm{V}, \%$ & $\begin{array}{c}\mathrm{x} \pm \mathrm{Sx} \\
(\mathrm{n}-7)\end{array}$ & $\mathrm{V}, \%$ & $\begin{array}{c}\mathrm{x} \pm \mathrm{Sx} \\
(\mathrm{n}-14)\end{array}$ & $\mathrm{V}, \%$ \\
\hline Age before slaughter, days & $591 \pm 9.9^{\mathrm{a}}$ & 6.5 & $567 \pm 39.3^{\mathrm{a}}$ & 15.5 & $661 \pm 9.4^{\mathrm{b}}$ & 3.8 & $655 \pm 14.3^{\mathrm{b}}$ & 8.2 \\
\hline $\begin{array}{l}\text { Live weight before } \\
\text { slaughter, kg }\end{array}$ & $534.1 \pm 8.82^{\mathrm{ac}}$ & 6.4 & $497.8 \pm 14.46^{\mathrm{b}}$ & 6.5 & $519.9 \pm 3.47^{\mathrm{bc}}$ & 1.8 & $542.1 \pm 6.32^{\mathrm{a}}$ & 4.4 \\
\hline $\begin{array}{l}\text { Daily weight gain from } \\
\text { birth to slaughter per day, } \mathrm{g}\end{array}$ & $831.9 \pm 15.60^{\mathrm{a}}$ & 7.3 & $810.2 \pm 42.90^{\mathrm{abc}}$ & 11.8 & $721.5 \pm 14.51^{\mathrm{b}}$ & 5.3 & $763.9 \pm 18.83^{\mathrm{c}}$ & 9.2 \\
\hline $\begin{array}{l}\text { Corrected live weight of } \\
600 \text { days }\end{array}$ & $542.0 \pm 9.34^{\mathrm{ac}}$ & 6.7 & $530.3 \pm 26.55^{\mathrm{abc}}$ & 11.2 & $476.4 \pm 8.62^{\mathrm{b}}$ & 4.8 & $503.3 \pm 11.43^{\mathrm{c}}$ & 8.5 \\
\hline
\end{tabular}

$\mathrm{a} b \mathrm{c}-$ significant differences between the study groups, $\mathrm{p} \leq 0.05$

Bulls average age in the research, before slaughtering was different, as in a result also different live weight before slaughtering. To make an objective research about bulls group data comparison, corrected live weight calculating on age of 600 days was made. Obtained results showed, that on spring born bulls with age 600 days reached the biggest live weight $-542.0 \mathrm{~kg}$, respectively these group bulls average daily weight gain from birth to slaughter per day was the biggest among all the groups $-831.9 \mathrm{~g}$.

On spring season born bulls corrected live weight at the age of 600 days was $11.7 \mathrm{~kg}$ more than on summer season born bulls, about $65.6 \mathrm{~kg}(\mathrm{p} \leq 0.05)$ more than on autumn season born bulls and about $38.7 \mathrm{~kg}$ more than on winter season born bulls. The lowest live weight growth was marked on autumn season born bulls, respectively -722 g. On spring season born bulls average daily weight gain from birth to slaughter per day was significantly more than then on autumn and winter seasons burn bulls ( $\mathrm{p} \leq 0.05)$.

The highest slaughter weight showed on autumn and winter seasons born bulls, respectively $275.5 \mathrm{~kg}$ and 274.8 $\mathrm{kg}$ (Table 2). The lowest slaughter weight was detected on summer season born bulls $-255.9 \mathrm{~kg}$ that was significantly lower than the other bulls slaughter weight in the research groups $(\mathrm{p} \leq 0.05)$. The Latvian study (Muižniece, Kairiša, 2016) proves that in organic farming conditions HE purebred bulls get carcass weight $298 \mathrm{~kg}$ before slaughter at the bull age of 615 days.

Table 2. On different seasons born Hereford purebred bulls slaughtering results

\begin{tabular}{|l|c|c|c|c|c|c|c|c|}
\hline \multirow{2}{*}{\multicolumn{1}{|c|}{ Indicators }} & \multicolumn{2}{|c|}{ Sp.S. bulls } & \multicolumn{2}{c|}{ So.S. bulls } & \multicolumn{2}{c|}{ Au.S. bulls } & \multicolumn{2}{c|}{ Wi.S. bulls } \\
\cline { 2 - 9 } & $\begin{array}{c}\mathrm{x} \pm \mathrm{Sx} \\
(\mathrm{n}-15)\end{array}$ & $\mathrm{V} \%$ & $\begin{array}{c}\mathrm{x} \pm \mathrm{Sx} \\
(\mathrm{n}-5)\end{array}$ & $\mathrm{V}, \%$ & $\begin{array}{c}\mathrm{x} \pm \mathrm{Sx} \\
(\mathrm{n}-7)\end{array}$ & $\mathrm{V}, \%$ & $\begin{array}{c}\mathrm{x} \pm \mathrm{Sx} \\
(\mathrm{n}-14)\end{array}$ & $\mathrm{V}, \%$ \\
\hline Slaughter weight, $\mathrm{kg}$ & $267.7 \pm 4.63^{\mathrm{a}}$ & 6.7 & $255.9 \pm 4.44^{\mathrm{b}}$ & 3.9 & $275.5 \pm 2.21^{\mathrm{a}}$ & 2.1 & $274.8 \pm 3.53^{\mathrm{a}}$ & 4.8 \\
\hline Dressing percentage, $\%$ & $50.1 \pm 0.47^{\mathrm{a}}$ & 3.6 & $51.5 \pm 0.96^{\mathrm{abc}}$ & 4.2 & $53.0 \pm 0.62^{\mathrm{b}}$ & 3.1 & $50.7 \pm 0.56^{\mathrm{ac}}$ & 4.2 \\
\hline
\end{tabular}

a b c - significant differences between the study groups, $\mathrm{p} \leq 0.05$

On autumn season born Hereford purebred bulls showed the highest dressing percentage $-53.1 \%$, that was significantly higher than on spring's $(50.0 \%)$ and winter's $(50.7 \%)$ season born bulls dressing percentage ( $\mathrm{p} \leq 0.05)$. Using 
different fattening technologies, other researchers found out that the average HE purebred bulls dressing percentage was higher (from 54.1\% - 56.0\%) than our study (Barton et al., 2006; Pesonen, Honkavaar \& Huuskonen, 2013).

In the research groups on different seasons born bulls carcass conformation was from points 2.4 to 2.6 (Table 3 ). On autumn season born bulls carcass conformation got the highest valuation -2.6 points. From this group $57 \%$ of bull carcasses were valuated with $\mathrm{R}$ muscle class and $43 \%$ of this group with $\mathrm{O}$ muscle class. On summer season born bull carcass got the lower valuation -2.4 points, $40 \%$ of this group carcasses got $\mathrm{R}$ muscle class, but $60 \%-\mathrm{O}$ muscle class. On spring and winter season born bull average valuation of carcass was 2.5 points, $50 \%$ carcass got valuation of muscles $\mathrm{R}$ and $50 \%$ got $-\mathrm{O}$. For carcass quality improvement it is possible to use also the Herford breed cows mating with others, more intensive breed bulls, who will provide offspring with more muscle mass and fast growth. As researchers admit that it is very important to choose right breed for mating to have high quality of cattle carcass (Keane, Moloney, 2009; Jukna et. al., 2010).

Table 3. Quality of bull carcasses

\begin{tabular}{|l|c|c|c|c|c|c|c|c|}
\hline \multirow{2}{*}{ Indicators } & \multicolumn{2}{c|}{ Sp.S. bulls } & \multicolumn{2}{c|}{ So.S. bulls } & \multicolumn{2}{c|}{ Au.S. bulls } & \multicolumn{2}{c|}{ Wi.S. bulls } \\
\cline { 2 - 8 } & $\mathrm{x} \pm \mathrm{Sx}$ & $\mathrm{V}, \%$ & $\mathrm{x} \pm \mathrm{Sx}$ & $\mathrm{V}, \%$ & $\mathrm{x} \pm \mathrm{Sx}$ & $\mathrm{V}, \%$ & $\mathrm{x} \pm \mathrm{Sx}$ & $\mathrm{V}, \%$ \\
\hline Conformation score, points & $2.5 \pm 0.13^{\mathrm{a}}$ & 20.4 & $2.4 \pm 0.24^{\mathrm{a}}$ & 22.8 & $2.6 \pm 0.20^{\mathrm{a}}$ & 20.8 & $2.5 \pm 0.14^{\mathrm{a}}$ & 20.8 \\
\hline Fat score, points & $2.1 \pm 0.07^{\mathrm{a}}$ & 12.5 & $2.4 \pm 0.24^{\mathrm{a}}$ & 22.8 & $2.0 \pm 0.00^{\mathrm{a}}$ & 0.0 & $2.0 \pm 0.00^{\mathrm{a}}$ & 0.0 \\
\hline
\end{tabular}

All the bull's carcass in the research groups were evaluated as 2 nd and 3rd fat class. No carcass got 1 st, 4th or 5th fat class. Fat score in the research groups were from points 2.0 to 2.4. On summer season born bulls carcass were with the highest fat score, got valuation 2.4 points, but on autumn and winter seasons born bull's carcass were with the lowest fat score, got valuation 2.0 points.

To find out the relationship between the fattening and slaughter traits, correlation analysis was performed (Table 4). The obtained results show, between the age before slaughter and average daily weight gain from birth to slaughter there is strong negative correlation (from $\mathrm{r}=-0.858$ to $=-0.977, \mathrm{p}<0.05$ ), except on spring season born bulls, in this group it was weak negative $(\mathrm{r}=-0.34)$. It can be observed that growing the fattening bull's age, live weight growth is decreasing.

Table 4. Bull fattening and slaughter trait phenotypic correlation

\begin{tabular}{|c|c|c|c|c|}
\hline Indicators & $\begin{array}{c}\text { Age before } \\
\text { slaughter, days }\end{array}$ & $\begin{array}{c}\text { Live weight before } \\
\text { slaughter, } \mathrm{kg}\end{array}$ & $\begin{array}{c}\text { Slaughter } \\
\text { weight, kg }\end{array}$ & $\begin{array}{c}\text { Dressing } \\
\text { percentage, } \%\end{array}$ \\
\hline \multicolumn{5}{|c|}{ Sp.S. bulls group } \\
\hline Live weight before slaughter, $\mathrm{kg}$ & 0.356 & - & - & - \\
\hline Slaughter weight, $\mathrm{kg}$ & 0.260 & $0.857 *$ & - & - \\
\hline Dressing percentage, $\%$ & -0.174 & -0.204 & 0.329 & - \\
\hline Daily weight gain from birth to slaughter, $g$ & -0.349 & $0.728 *$ & $0.722 *$ & 0.046 \\
\hline Conformation score, points & 0.341 & 0.101 & 0.441 & $0.637 *$ \\
\hline Fat score, points & 0.055 & 0.290 & 0.191 & -0.154 \\
\hline \multicolumn{5}{|c|}{ So.S. bulls group } \\
\hline Live weight before slaughter, $\mathrm{kg}$ & 0.395 & - & - & - \\
\hline Slaughter weight, kg & 0.067 & 0.776 & - & - \\
\hline Dressing percentage, $\%$ & -0.565 & -0.820 & -0.275 & - \\
\hline Daily weight gain from birth to slaughter, $g$ & $-0.906^{*}$ & 0.027 & 0.311 & 0.266 \\
\hline Conformation score, points & -0.612 & -0.728 & -0.327 & 0.830 \\
\hline Fat score, points & -0.612 & -0.728 & -0.327 & 0.830 \\
\hline \multicolumn{5}{|c|}{ Au.S. bulls group } \\
\hline Live weight before slaughter, $\mathrm{kg}$ & $-0.761 *$ & - & - & - \\
\hline Slaughter weight, $\mathrm{kg}$ & 0.729 & -0.240 & - & - \\
\hline Dressing percentage, $\%$ & $0.943^{*}$ & -0.745 & $0.826^{*}$ & - \\
\hline Daily weight gain from birth to slaughter, $g$ & $-0.977 *$ & $0.881 *$ & -0.619 & $-0.937 *$ \\
\hline Conformation score, points & 0.573 & -0.354 & $0.846^{*}$ & $0.786^{*}$ \\
\hline \multicolumn{5}{|c|}{ Wi.S. bulls group } \\
\hline Live weight before slaughter, $\mathrm{kg}$ & 0.101 & - & - & - \\
\hline Slaughter weight, $\mathrm{kg}$ & -0.309 & $0.598 *$ & - & - \\
\hline Dressing percentage, $\%$ & -0.469 & -0.348 & $0.544 *$ & - \\
\hline Daily weight gain from birth to slaughter, $g$ & $-0.858^{*}$ & 0.409 & $0.568 *$ & 0.237 \\
\hline Conformation score, points & -0.293 & -0.373 & 0.181 & $0.601 *$ \\
\hline
\end{tabular}

Between bull live weight before slaughtering and obtained slaughter weight exists averagely close to close positive correlation (from $r=0.598$ to $r=0.857, p<0.05$ ), except on autumn season born bulls, in this group the correlation between was weak negative $(r=-0.24)$. Similar correlation between these traits was also found in the research that was made in Lithuania (Pečiulaitien et. al., 2015), where in the research included bull group was found strong positive correlation ( $\mathrm{r}=$ $0.93, \mathrm{p}<0.001)$ between live weight before slaughter and slaughter weight. 


\section{Proceedings of the $8^{\text {th }}$ International Scientific Conference Rural Development 2017}

Between dressing percentage and conformation score there is average strong to strong correlation (from $r=0.60$ $-r=0.83$ ), that shows, bulls from who the dressing percentage got more was better developed carcass musculature. In the all of the groups, except those on summer season, correlation values were significant. On autumn season group born bulls features, slaughter weight and daily weight gain from birth to slaughter, also dressing percentage and daily weight gain from birth to slaughter, obtained correlation value was negative from $r=-0.61$ to $r=-0.93$, but correlation values in the other groups of the research was positive.

\section{CONCLUSIONS}

The average age of realization of bulls of the research groups was from 567 days to 661 day. On the autumn and winter season born bulls before slaughtering were significantly older, respectively 661 and 655 days, and live weight respectively $519.9 \mathrm{~kg}$ and $542.1 \mathrm{~kg}$. The best results of slaughter weight also showed bulls from this research groups, respectively $275.5 \mathrm{~kg}$ and $274.8 \mathrm{~kg}$.

Calculation of corrected live weight at the age 600 days showed that in spring born bulls at age 600 days received the highest live weight $-542.0 \mathrm{~kg}$, respectively also the average live weight growth from this bull group was the highest between other groups $-831.9 \mathrm{~g}$, that shows that on spring season born bulls are faster-growing.

The highest slaughtering outcome showed bulls born in autumn $-53.0 \%$, that was significantly higher than spring $(50.1 \%)$ and winter $(50.7 \%)$ seasons born bulls slaughtering outcome $(\mathrm{p} \leq 0.05)$.

All carcasses of the groups of the research were valuated with $\mathrm{R}$ and $\mathrm{O}$ muscle class and with 2nd and 3rd fat class. On autumn season born bulls carcass got the highest mark- 2.6 points. In this research group $57 \%$ of bull carcass were valuated with muscle class $\mathrm{R}$ and $43 \%$ with muscle class O. For carcass quality improvement purposes farms in Latvia need to have thoughtful Herford breed's animal selection to have possibility to choose for cattle fattening those with expressed muscles and in slaughtering results carcasses are evaluated at least with $\mathrm{R}$ class.

On summer season born bulls carcass were with higher fat level, got mark 2.4 points, but on autumn and winter season born bull's carcass were with smaller fat level, got mark 2.0 points. The fat level of the carcass is one of the important factors of price, that is why fattening the cattle very important attention should pay for quality of forage, to ensure more carcass with big enough fat level.

Analysis of correlation shows that increasing fattening bull's age, live weight growth is decreasing. That is why it is important to realize fattening cattle in the period which is achieved while maximal live weight growth, thereby providing efficiency of production and fattening profitability. Between dressing percentage and conformation score exists medium close and close correlation (from $r=0.60-r=0.83$ ), that shows that bulls from who dressing percentage was higher the musculature of carcass was better developed.

\section{REFERENCES}

1. Adams, D.C., Clark, R.T., Klopfenstein, T.J., Volesky, J.D. 1996. Matching the cow with forage resources. Rangelands, Vol. 18. pp. $57-62$.

2. Barton, L., Rehak, D., Teslik, V., Bures, D., Zahradkova, R. 2006. Effect of breed on growth performance and carcass composition of Aberdeen Angus, Charolais, Hereford and Simmental bulls. Czech Journal of Animal Science, Vol. 51, No. 2, pp. 47-53. https://doi.org/10.17221/3908-CJAS

3. Dadi, H., Jordaan, G.F., Schoeman, S.J., J. Van der Westhuizen, J, 2002. The effect of Charolais and Hereford sires and straightbred and crossbred dams on pre-weaning growth of calves. South African Journal of Animal Science, Vol. 32, No. 1, pp. 38-43. https://doi.org/10.4314/sajas.v32i1.3789

4. Dannenberger, D., Nuernberg, K., Nuernberg, G. Ender, K. 2006. Carcass - and meat quality of pasture vs concentrate fed German Simmental and German Holstein bulls. Archiv Tierzucht, Vol. 49, No. 4, pp. 315-328.

5. Jukna, Ch., Jukna, V., Korsukovas, A., Peciulaitiene, N. 2010. The influence of beef breed bulls on Lithuanian black and white cattle production and quality. Veterinary Medicine and Zootechnics, Vol. 46, No. 68, pp. 20-23.

6. Keane M. G., Moloney A. P. 2009. A comparison of finishing systems and duration for spring-born Aberdeen AngusxHolsteinFriesian and Belgian BluexHolstein-Friesian steers. Livestock Science, Vol. 124, No. 1, pp. $223-232$. https://doi.org/10.1016/j.livsci.2009.02.001

7. Koknaroglu H., Loy D. D. Wilson D. E., Hoffman M. P., Lawrence J. D. 2005. Factors Affecting Beef Cattle Performance and Profitability. The Professional Animal Scientist, Vol. 21, pp. 286-296. https://doi.org/10.15232/S1080-7446(15)31220-1

8. Lujāne, B., Ošmane, B., Jansons, I. 2013. Production of cattle meat. Latvia University of Agriculture Biotechnology and Veterinary Medicine Research Institute „Sigra”, Sigulda, Latvia.

9. Krupa, E., Oravcová, M, Polák, P., Huba, J., Krupová, Z. 2005. Factors affecting growth traits of beef cattle breeds raised in Slovakia. Czech Journal of Animal Science, Vol 50, No. 1, pp. 14-21. https://doi.org/10.17221/3990-CJAS

10. May S. G., Dolezal H. G. Gill D. R., Ray F. K., Buchanan D. S. 1992. Effects of days fed. carcass grade traits. and subcutaneous fat removal on postmortem muscle characteristics and beef palatability. Journal of Animal Science, Vol. 70, pp. 444-453. https://doi.org/10.2527/1992.702444x

11. Muižniece I., Kairiša, D. 2016. Different beef breed cattle fattening results analysis. Proceedings of the Annual 22st International Scientific Conference "Research for rural development 2016”, Vol 1, pp. 57-62, Latvia University of Agriculture. 
12. Pečiulaitienė N., Jukna V., Meškinytė-Kaušilienė E., Kerzienè S., Moleikaitienė S. 2015. Effects of weight and age on carcass yield and conformation of cattle. Biotechnology in Animal Husbandry, Vol. 31, No. 1, pp. 73-84. https://doi.org/10.2298/BAH1501073P

13. Pečiulaitienė N., Jukna V., Meškinytė-Kaušilienė E., Kerzienè S., Moleikaitienė S. 2015. Effects of weight and age on carcass yield and conformation of cattle. Biotechnology in Animal Husbandry, Vol. 31, No. 1, pp. 73-84. https://doi.org/10.2298/BAH1501073P

14. Stockton M. C., Adams D. C., Wilson R. K., Klopfenstein T. J., Clark R. T., and Carriker G. L. 2007. Production and economic comparison to two calving dates for beef cows in the Nebraska Sandhills. The Professional Animal Scientist, Vol. 23, pp. 500-508. https://doi.org/10.1532/S1080-7446(15)31011-1

15. Thrift F. A., Thrift T. A. 2004. Ramifications of weaning spring - and fall - born calves early or late relative to weaning at conventional ages. The Professional Animal Scientist, Vol 20, pp. 490-502. https://doi.org/10.15232/S1080-7446(15)31353-X 